\title{
Gender and Oral Manifestations of HIV Infection Among Adult Nigerians
}

\author{
O.N. Obuekwe and A.N. Onunu ${ }^{2}$
}

\begin{abstract}
Oral manifestations were studied in 305 adult Nigerians with HIV infection. Data collected were demographic (age, sex, marital status, educational status and occupation) and clinical (mode of transmission, general manifestations and oral manifestations of HIV infection). The chi- square test was used in test for significance between variables and $\mathrm{p}$ values less than 0.05 were regarded as significant. A total of $47.5 \%$ patients had oral manifestations. There were $67.6 \%$ females and $32.4 \%$ males $(p<0.001)$. The patients ranged in age from 19-70 years. Heterosexual contact with multiple sex partners was the most common mode of transmission of infection $(42.9 \%$ in females and $74.5 \%$ in males, $\mathrm{p}<0.05)$. Candidiasis was the most common oral manifestation $(78.6 \%$ in females and $78.7 \%$ in males $\mathrm{p}>0.05$ ). The study concluded that similar demographic and clinical characteristics were observed in the occurrence of oral manifestations of HIV infection in both male and female Nigerians. (Rev Afr Santé Reprod 2006; 10[2]:81-89)
\end{abstract}

\begin{abstract}
Les genres et les manifestations orales de l'infection du VIH chez les adultes nigérians. Les manifestations ont été étudiées chez 305 adultes nigérians qui ont été infectés par le VIH. Les données collectées étaient démographiques (âge, sexe, état civil, niveau d'instruction et le métier) et cliniques (mode de transmission, les manifestations générales et les manifestations orales de l'infection VIH). Le test $\mathrm{Ch}^{2}$ a été utilisé pour rechercher la signification entre les variables et les valeurs p qui sont inférieures à 0,05 ont été considérées comme étaient significatives. Au total, $47,5 \%$ des patients avaient des manifestations orales. Il y avaient $67,6 \%$ femmes et $32,4 \%$ hommes $(p<0,02)$. Les âges des patients ont variés entre 19 et 70 ans. Le contact hétérosexuel avec les partenaires sexuels multiples était le mode de transmission de l'infection ( $42,9 \%$ chez les femmes et $74,5 \%$ chez les hommes ( $p>0,05)$. L'étude avait conclu que les caractéristiques cliniques et démographiques ont été constatées dans les éventualte des manifestations orales de l'inffection du VIH chez les hommes et les femmes nigérians. (Rev Afr Santé Reprod 2006; 10[2]:81-89)
\end{abstract}

KEY WORDS: Transmission, heterosexul contact, sex partners

${ }^{1}$ Department of Oral and Maxillofacial Surgery, ${ }^{2}$ Department of Medicine, University of Benin Teacbing Hospital, Benin City, Edo State, Nigeria

Correspondence: Dr. O.N. Obuekwe, School of Dentistry, University of Benin, P.M.B 1154, Benin City, Edo State, Nigeria.E-Mail:Oxobuekwe@Yahoo.Com 


\section{Introduction}

Perhaps, no singular event has had a profound impact on oral health and oral health-care delivery as the human immunodeficiency virus/acquired immunodeficiency syndrome (HIV/AIDS) pandemic. ${ }^{1}$ Notable in this regard is the emergence of oral opportunistic manifestations and cross infection control. ${ }^{2-5}$ Oral manifestations were among the early documented signs of HIV infection and to date, over 40 manifestations have been described. ${ }^{6-7}$ Oral manifestations in the most, appear as opportunistic infections and are seen in 70 to $90 \%$ of infected individuals. ${ }^{8,9}$

Oral manifestations of HIV infection are important for several reasons. They may represent the first signs of the disease. ${ }^{6}$ This is significant from a diagnostic and therapeutic viewpoint. Early recognition and subsequent antiretroviral therapy will reduce the morbidity and mortality associated with the disease. ${ }^{7,10}$ Oral manifestations can serve as clinical correlates of CD4 count and viral load ${ }^{3}$ as these two parameters are highly predictive markers of severe immune deterioration and disease progression. ${ }^{7}$

Oral manifestations can serve as criteria for entry into clinical trials ${ }^{3}$. They are also included in natural history studies, staging and classification schemes for HIV infections. ${ }^{3}$

There is an increasing awareness that health and disease are affected by gender differences. ${ }^{11}$ An earlier study had observed the paucity of research relating oral manifestations of HIV infection to gender. ${ }^{12}$ This same report ${ }^{12}$ showed that $33 \%$ of the study population were females with a mean age of 33 years and that the prevalence of HIV- related oral lesion was significantly higher in women than in men. Also, Khongkunthain, et. al. ${ }^{13}$ showed that $85.1 \%$ of their study population were females with a median age of 31.3 years. However, they reported that men were more significantly affected by the oral manifestation of HIV infection. In both studies $^{12,13}$ candidiasis was the most common HIV- related oral manifestation. Shiboski, ${ }^{14}$ in a review of the epidemiology of HIV- related oral manifestations in women spanning over 15 years found that some lesions like hairy leukoplakia and Kaposi's sarcoma appeared to be gender related.

A search of the literature has shown that very little data exists on the subject of gender and oral manifestations of HIV infection in our environment. The aim of this study was to contribute to the scanty literature on the spectrum of oral manifestations related to gender in HIV infection and to compare the findings with those reported in the literature. An understanding of the gender differences in oral manifestations of HIV infection will lead to improved management of the patients affected.

\section{Methods}

During an 18-month period (June 2002 to December 2003), consecutive patients with HIV infection were seen at the medicine and dental clinics of the University of Benin Teaching Hospital (UBTH), Edo State, Nigeria. The dental patients were those whose medical history and oral lesions led to a suspicion of HIV infection and subsequent positive report on retroviral screening, while the medical patients were already diagnosed HIV/AIDS cases and oral examination was included as a part of the physical examination. In both cases, pre-test counseling was done and consent obtained before an ELISA test. Positive results from two different ELISA techniques were taken as confirmatory evidence of HIV antibodies. ${ }^{15}$ Data documented included demographic-[age, sex, marital status, occupation, educational status (primary, secondary or tertiary)] and clinical-[mode of transmission, general manifestations and oro-facial manifestations related to HIV infection]. Three dental surgeons and a physician evaluated the patients according to the method outlined by Zain, et. al. ${ }^{16}$ Diagnosis of oro-facial manifestations was based on clinical findings, supplemented by biopsy were clinically, a diagnosis was not possible. Descriptive statistics and statistical analysis was done with the SPSS.

African Journal of Reproductive Health Vol. 10 No.2 August 2006 
The chi-square test was used to test for significance and $\mathrm{p}$ values below 0.05 were regarded as significant.

A limitation with this study lies in the fact that since all dental patients were not screened for HIV, it is likely that some patients with HIV disease but no oral manifestation may have been excluded. This would affect the incidence and prevalence of the disease and the number of patients with oral manifestations.

\section{Results}

Three hundred and five patients were seen during the study period. Of these, $145(47.5 \%)$ had orofacial manifestations of HIV infection.

\section{Age and Gender}

There were 98(67.6\%) females and 47(32.4\%) males giving a female to male ratio of $2: 1$. The females ranged in age from 19-60 years with a mean age of 33.2 years (SD 6.75 years). The males were aged 26-70 years with a mean age of 36.3 years (SD 9.98 years) (Table 1 ). These differences in gender and age showed a statistically significant association $\left(\mathrm{X}^{2}=32.049, \mathrm{p}<0.001\right)$

\section{Marital Status}

Table 1 showed the marital status of patients. Most were married-females $46(46.9 \%)$ and males $39(83.0 \%)$. These differences were statistically significant $\left(\mathrm{X}^{2}=18.780, \mathrm{p}<0.001\right)$.

Table 1. Demographic characteristics of patients

\begin{tabular}{|c|c|c|}
\hline Age range (in years) & Female $(n=98)(\%)$ & Male $(n=47)(\%)$ \\
\hline $21-30$ & $47(47.9 \%)$ & $6(12.8 \%)$ \\
\hline $31-40$ & $30(30.6 \%)$ & $17(36.1 \%)$ \\
\hline $41-50$ & $15(15.3 \%)$ & $15(31.9 \%)$ \\
\hline $51-60$ & $6(6.1 \%)$ & $7(14.9 \%)$ \\
\hline $61-70$ & - & $2(4.3 \%)$ \\
\hline \multicolumn{3}{|l|}{ Marital status } \\
\hline Married & $46(46.9 \%)$ & $39(83.0 \%)$ \\
\hline Single & $36(36.7 \%)$ & $8(17.0 \%)$ \\
\hline Widow & $13(13.3 \%)$ & - \\
\hline Divorced & $3(3.1 \%)$ & - \\
\hline \multicolumn{3}{|l|}{ Occupation } \\
\hline Trading & $42(42.8 \%)$ & $23(48.9 \%)$ \\
\hline Student & $13(13.3 \%)$ & $2(4.3 \%)$ \\
\hline Tailoring & $11(11.2 \%)$ & $6(12.8 \%)$ \\
\hline Teaching & $10(10.2 \%)$ & $2(4.3 \%)$ \\
\hline Civil servant & $8(8.2 \%)$ & $13(27.6 \%)$ \\
\hline House wife & $7(7.1 \%)$ & - \\
\hline Cashier & $3(3.1 \%)$ & - \\
\hline Unemployed & $4(4.1 \%)$ & $1(2.1 \%)$ \\
\hline \multicolumn{3}{|l|}{ Education } \\
\hline Primary & $38(38.8 \%)$ & $17(36.1 \%)$ \\
\hline Secondary & $34(34.7 \%)$ & $20(42.6 \%)$ \\
\hline Tertiary & $26(26.5 \%)$ & $10(21.3 \%)$ \\
\hline
\end{tabular}

African Journal of Reproductive Health Vol. 10 No.2 August 2006 


\section{Occupation}

Trading was the most common occupation of the patients (females 42 or $42.6 \%$ ) and males (37 or $31.9 \%$ ) $\}$ (Table 1) There was a significant association between gender and occupation $\left(\mathrm{X}^{2}\right.$ $=33.692, \mathrm{p}<0.001)$.

\section{Educational Status}

Thirty-eight $(38.8 \%)$ of females had primary education compared with $17(36.1 \%)$ of males (Table 1). These differences were not statistically significant $\left(\mathrm{X}^{2}=1.599, \mathrm{p}>0.05\right)$.

\section{Mode of Transmission}

Heterosexual contact with multiple sex partners was the most common mode of transmission in female (42 or $42.9 \%$ ) and male (35 or $74.5 \%$ ) patients. Also in a higher proportion of females (20 or $20.4 \%$ ), the mode of transmission was unknown (Table 2) These differences were statistically significant $\left(\mathrm{X}^{2}=12.252, \mathrm{p}<0.05\right)$.

\section{Table 2: Mode of Transmission of infection}

\section{General Manifestations}

The most common medical findings among female patients were weight loss $41(41.8 \%)$, fever $39(39.8 \%)$, cough $31(31.6 \%)$ and skin rashes 15(15.3\%). Forty-two (42.9\%) patients had more than one general manifestation. Among males the most common findings were weight loss $23(48.9 \%)$, fever $23(48.9 \%)$, diarrhoea $23(48.9 \%)$, skin rashes 9(19.1) cough 7(14.9). A further 9(19.1\%) were asymptomatic. More than one medical finding was seen in 38(80.9\%) patients (Table 3)

\section{Oro-Facial Manifestations}

The chi-square test showed non-significant differences between oro-facial manifestations of HIV and educational level (males: $\mathrm{X}^{2}=26.356$, p>0.05; females: $\left.X^{2}=38.025, p>0.05\right)$, as well as between oro-facial manifestations and occupation (males: $\mathrm{X}^{2}=76.490, \mathrm{p}>0.05$; females: $\left.\mathrm{X}^{2}=125.937, \mathrm{p}>0.05\right)$. However, a statistically significant difference was observed between orofacial manifestations and mode of transmission

\begin{tabular}{lll}
\hline Mode & Female (\%) & Male (\%) \\
\hline Heterosexual contact with multiple partners & $35(74.5 \%)$ & $6(12.8 \%)$ \\
Heterosexual contact with single partner & $42(42.9 \%)$ & - \\
Blood transfusion & $33(33.7 \%)$ & $1(2.1 \%)$ \\
Non-sterile instrumentation & $2(2.0 \%)$ & $5(10.6 \%)$ \\
Unknown & $1(1.0 \%)$ & $\mathbf{4 0} \%(\mathbf{1 0 0 \% )}$ \\
\hline Total & $20(20.4 \%)$ & $\mathbf{9 8 ( 1 0 0 \% )}$ \\
\hline
\end{tabular}

Table 3: Distribution of general manifestations of HIV infection

\begin{tabular}{lll}
\hline Manifestation & Female (\%) & Male (\%) \\
\hline Weight loss & $41(41.8 \%)$ & $23(48.9 \%)$ \\
Fever & $39(39.8 \%)$ & $23(48.9 \%)$ \\
Cough & $31(31.6 \%)$ & $7(14.9 \%)$ \\
Skin rashes & $15(15.3 \%)$ & $9(19.1 \%)$ \\
Pulmonary tuberculosis & $3(3.1 \%)$ & - \\
Diarrhoea & - & $23(48.9 \%)$ \\
Anorexia & $8(\%)$ & $3(\%)$ \\
Dyspnoea & $6(6.1 \%)$ & $3(6.4 \%)$ \\
Vomiting & $3(3.1 \%)$ & $2(4.3 \%)$ \\
Chest pain & $2(2.0 \%)$ & $1(2.1 \%)$ \\
\hline
\end{tabular}


of HIV amongst females $\left(\mathrm{X}^{2}=64.203, \mathrm{p}<0.05\right)$ but not amongst males (X2 $=16.847, \mathrm{p}>0.05)$. Table 4 showed the spectrum of oro-facial manifestations of HIV infection by gender. Candidiasis in its various forms was the most common oral finding in females $77(78.6 \%)$ and males $37(78.7 \%)$. There was no significant association between the oral manifestations of HIV infection and gender $\left(X^{2}=26.045, p>0.05\right)$. Three (3.1\%) females and 12(25.5\%) males had more than 1 oral manifestation.

\section{Discussion}

It would appear that the prevalence of HIVrelated oral diseases have not been extensively documented among females. ${ }^{12}$ In this study, females comprised most $(67.6 \%)$ of HIV positive $(\mathrm{HIV}+)$ patients with oral manifestations. This is consistent with several reports. ${ }^{13,17-19}$ However, some studies have shown a higher prevalence among males. ${ }^{20-22}$ The reason for this gender difference in presentation is not immediately apparent but may be related to the fact that women react to health promotion more positively and for many oral conditions, women come forward for treatment much more frequently. ${ }^{11}$ The mean age of the patients in this study is similar to reports in the literature. ${ }^{12,13,17}$ However, women were infected much earlier (19 years vs. 26 years for males) while males were infected more into old age ( 70 years vs. 60 years for females). This is probably because girls are more likely to engage in sexual activity (the most common mode of transmission of HIV infection in this study) much earlier than boys. Younger females are also more likely to consort with older men who in turn are more likely to be HIV+. Most of the patients in this study were married ( $46.9 \%$ for females and $83.0 \%$ for males). This is consistent with the report by Garcia- Vazquez, et. al. ${ }^{23}$ The patients in this study were engaged in a diverse range of occupation which ordinarily did not confer a high risk for HIV infection. Several reports have shown a similar trend. ${ }^{24-26}$ For both gender there were more patients with primary and secondary education than those that attained tertiary level education ( $\mathrm{p}>0.05)$. Many studies on HIV infection and literacy levels have shown a high prevalence among the less educated. ${ }^{27-29}$ However, some studies have also shown that the social elite is increasingly affected..$^{30,31}$

\section{Table 4: Distribution of oro-facial manifestations of HIV infection by gender}

\begin{tabular}{llll}
\hline & Oral manifestations & Females (\%) & Males (\%) \\
\hline 1. & Candidiasis & & \\
a. $\quad$ Thrush (Pseudomembraneous candidiasis) & $63(64.3 \%)$ & $28(59.6 \%)$ \\
b. $\quad$ Erythematous candidiasis & $6(6.1 \%)$ & $5(10.6 \%)$ \\
c. Chronic hyperplastic & $3(3.1 \%)$ & $4(8.5 \%)$ \\
d. Angular chelitis & $5(5.1 \%)$ & - \\
e. Chronic atrophic & - & $2(4.3 \%)$ \\
2. $\quad$ Oral ulcers & $5(5.1 \%)$ & $3(6.4 \%)$ \\
3. Kaposi's sarcoma & $3(3.1 \%)$ & - \\
4. Hairy leukoplakia & - & $3(6.4 \%)$ \\
5. Herpetic infection & $2(2.0 \%)$ & $4(8.5 \%)$ \\
6. Linear gingival erythema & $3(3.1 \%)$ & $3(6.4 \%)$ \\
7. Xerostomia & $3(3.1 \%)$ & $1(2.1 \%)$ \\
8. $\quad$ Bilateral parotid gland swelling & $1(1.0 \%)$ & - \\
9. Hyperpigmentation & $1(1.0 \%)$ & $2(4.3 \%)$ \\
10. Gingival bleeding & $1(1.0 \%)$ & - \\
11. Trigeminal neuralgia & - & $1(2.1 \%)$ \\
12. Facial palsy & - & $1(2.1 \%)$ \\
13. Cervical lymphadenopathy & $5(5.1 \%)$ & $2(4.3 \%)$ \\
\hline
\end{tabular}

African Journal of Reproductive Health Vol. 10 No.2 August 2006 
Heterosexual intercourse with multiple sex partners was the dominant mode of transmission among the patients in this study. This is consistent with the finding that in sub-Saharan Africa heterosexual contact was most common mode of transmission of HIV. ${ }^{19,32}$ This study did not encounter homosexual contact or intravenous drug use more common in highly industrialised countries. ${ }^{33-35}$ This study also encountered a low incidence of patients infected through blood transfusions and the use of non-sterile surgical instruments although this may have a relationship with the high number of patients who did not know how they got infected. The mode of transmission of HIV may have a bearing on the prevalence of oral manifestations. ${ }^{35}$

Apart from 9(19.1\%) males in this study, most patients had developed at least one medical condition attributable to HIV infection, suggesting disease progression. ${ }^{7}$ Although some oral diseases and conditions have a weak association with HIV infection, others are strongly associated with the disease, and a few are acquired immune deficiency syndrome (AIDS) defining in nature. ${ }^{7}$

In this study, there were no significant differences in the occurrence of oral manifestations of HIV infection in either gender $(\mathrm{p}>0.05)$. This differs from the report of Khongkunthian, et. al., ${ }^{13}$ which found that men were significantly more affected by oral manifestations than women.

Candidiasis was the most common oral condition observed in both gender in this study. This is consistent with many reports. ${ }^{13,14,17-19}$ As with these reports ${ }^{13,14,17-19}$ thrush (pseudomembraneous candidiasis) was the most common variety seen. The association of oral candidiasis with HIV infection was recognized very early in the HIV/AIDS pandemic. ${ }^{6}$ The different forms of candidiasis carry different prognostic significance. For example, erythematous candidiasis is a less powerful predictor of advanced HIV disease than thrush (pseudomem-braneous candidiasis). ${ }^{36}$ Non-significant differences $(\mathrm{p}>0.05)$ were seen in the occurrence of candidiasis amongst females and males.

The appearance of aphthous like ulcers is one of the clinical markers for HIV infection. ${ }^{37}$ The aetiology of oral ulcers include lymphoma, herpes simplex, histoplamosis and herpes zoster infections. ${ }^{38,39}$ More oral ulcers were seen in females than in males $(\mathrm{p}<0.05)$. Kaposi's sarcoma was the only malignancy recorded in this study. It is the most common oral malignancy associated with HIV infection and it accounts for $90 \%$ of all cancers in $\mathrm{HIV}+$ patients. ${ }^{37,40}$ Although a study ${ }^{14}$ has found that the prevalence of Kaposi's sarcoma was significantly less common in women, the only cases of Kaposi's sarcoma seen in this study occurred in females $(p>0.05)$. Kaposi's sarcoma is significantly associated with death in HIV disease. ${ }^{41}$

Herpetic infection was seen as herpetic stomatitis and herpes zoster, affecting more males than females ( $p>0.05)$. Infection with the herpes zoster virus is neither a marker of deteriorating immune function ${ }^{42}$ nor is it significantly associated with death. ${ }^{41}$ Hairy leukoplakia appears as corrugated or velvety (hairy) white plaques on the lateral borders of the tongue. ${ }^{43}$ As is consistent with other reports, this study found that only males $(\mathrm{p}>0.05)$ presented with leukoplakia. ${ }^{43-45}$ However, Muzyka et. al,46 found hairy leukoplakia in $5.8 \%$ of women who were HIV1 positive. Periodontal disease occurs in the range of $2.8 \%-33 \%$ in HIV infection. ${ }^{30}$ In this study, linear gingival erythema was seen in $3.1 \%$ of females and $6.4 \%$ of males. Arendorf et a ${ }^{47}$ found combined gingival and periodontal lesions in $8.5 \%$ of their study population. The more severe necrotizing gingivitis and necrotizing ulcerative periodontitis were not seen in this study. Schdiod $t^{48}$ also reported similar findings. Salivary gland disease in HIV infection can occur as xerostomia or as glandular enlargement. ${ }^{49}$ Xerostomia may be seen in $10-15 \%$ of patients with HIV infection. This is usually the result of HIV gland disease or secondary to medications 
which may produce dry mouth symptoms. ${ }^{49}$ The cervical lymphadenopathy seen in HIV infection is a part of the generalized lymphadenopathy and could be the most prevalent oro-facial manifestation. ${ }^{49}$ The peripheral nervous system is frequently involved in HIV infecton ${ }^{50,51}$ In this study, trigeminal neuralgia and facial palsy were seen in $1 \%$ of males. They usually represent early onset symptoms and late involvement may suggest severe immunodeficiency or tumours involving the central nervous system. ${ }^{51,52}$

In conclusion, this study showed that similar demographic and clinical characteristics were observed in the occurrence of oral manifestations of HIV infection in both male and female Nigerians. These findings are also comparable to those documented in the literature.

\section{REFERENCES}

1. DePaola LG. Managing the care of patients infected with blood borne diseases. JADA 2003; 134: 350358.

2. Wiebe CB, Epstein JB. An atlas of HIV- associated oral lesions: a new classification and diagnostic criteria. J Can Dent Assoc 1997; 63: 288-294.

3. Greenspan JS. Sentinels and signposts: the epidemiology and significance of the oral manifestations of HIV disease. Oral Dis 1997; 3:S13-17.

4. De-Jesus-Campos GO, Nicholoff TJ Jr, Valenzuela RM. General and oral manifestations of human immunodeficiency virus infection: A general overview with guidelines for infection control in the dental practice 1992; 44:4-14.

5. Kohn WG, Harte JA, Malvitz DM, Collins AS, Cleveland JL, Eklund KJ. Guidelines for infection control in dental care settings - 2003 JADA 2004; 135:33- 45.

6. PindborgJJ. Classification of oral lesions associated with HIV infection. Oral Surg Oral Med Oral Pathol 1989; 67:292-295.

7. Lynch DP. Oral manifestations of HIV disease: An update. Semin Cutan Med Sung 1997; 16: 257-264.

8. McCarthy GM. Host factors associated with HIV related oral candidiasis. A review. Oral Surg Oral Med Oral Pathol 1992; 73:181-186.

African Journal of Reproductive Health Vol. 10 No.2 August 2006
9. Weinert M, Grimes RM, Lynch DP. Oral manifestations of HIV disease. Ann Intern Med 1996; 125:485-496.

10. Patton LL, Shugars DC. Immunization and viral markers of HIV-I disease progression: implications for dentistry. JADA 1999; 130:1313-1322.

11. Zakrzewska JM. Women as dental patients: are there any gender differences? Int Dent. J 1996; 46:548-557.

12. Campsi G, Pizzo G, Mancuso S, Margiota V. Gender differences in human immunodeficiency virus- related oral lesions: An Italian study. Oral Surg Oral Med Oral Pathol Oral Radiol Endod 2001; 91; 546-551.

13. Khongkunthian P, Grote M, Isaratanan W, Plyaworawong S, Reichart PA. Oral manifestations in HIV-positive adults from Northern Thailand. $J$ Oral Pathol Med 2001; 30:220-223.

14. Shiboski CH. Epidemiology of HIV-related oral manifestations in women: A review. Oral Dis 1997; 3:S18-217.

15. Joint United Nation Programme on HIV/AIDS. Revised recommendations for the selection and use of HIV antibody tests. Wkly Epidemiol Rec 1997; 72:81-88.

16. Zain RB, Razak IA, Ikeda N, Axell T, Downer MC. Training examiners for a national epidemiological survey of oral mucosal lesions. Int Dent J 1996; 46:536-542.

17. Butt FM, Chindia ML, Vaghela VP, Mandalia K. Oral manifestations of HIV/AIDS in a Kenyan provincial hospital. East Afr Med J 2001; 78:398401.

18. Shiboski CH, Hilton JF, Neuhaus JM, Canchola A, Greenspan D. Human immunodeficiency virusrelated oral manifestations and gender. A longitudinal analysis. The University of California, San Francisco Oral AIDS Center Epidemiology Collaborative Group. Arch Intern Med 1996; 156:2249-2254.

19. Onunu AN, Obuekwe ON. HIV- related oral diseases in Benin City, Nigeria. West AfrJ Med 2002; 21:9-11.

20. Patton LL, McKaig RG, Strauss, Eron JJ. Oral manifestations of HIV in a southeast USA population. Oral Dis 1998; 4:164-169. 
21. Bendick C, Scheifele C, Reichart PA. Oral Manifestation in 101 Cambodians with HIV and AIDS. J Oral Pathol Med 2002; 31:1-4.

22. Jonsson N, Zimmerman M, Chidzonga MM Jonsson K. Oral manifestations in 100 Zimbabwean HIV/AIDS patients referred to a specialist Centre: Cent AfrJ Med 1998; 44:31-34.

23. Garcia-Vazquez, Cedillos RA, Wheeler DA. Clinical and demographic features of HIV infection in EI Salvador. Rev Panam Salud Publica 2003; 13:327-331.

24. Kravitz JD, Mandel R, Petersen EA, Nyaphisis M, Human D. Human Immunodeficiency virus seroprevalence in an occupational cohort in a South Africa Community. Arch Intern Med 1995; 155:1601-1604.

25. Bansal RK, Nia AB. Truck crew and risk of contraction of STDS, including HIV: encouraging the use of condom by the method of applying theories. Indian J Med Sci 1998; 25: 253-264.

26. Muhammad B, Eligius L, Mugusi F et al, Prevalence and pattern of skin diseases in relation to $\mathrm{CD} 4$ counts among HIV infected police officers in Dar es Salaam. Trop Doct 2003; 33:44-48.

27. Msimuko AK. AIDS education for a low literacy audience in Zambia. IPPF Med Bull1988; 22:3-4

28. Hyde S, White S. Challenges of education and cultural diversity in the workplace. AIDS Health Promot Exch 1993; 2:4-7.

29. Singh S, Fukuda H, Ingle GK, Tatara K. Knowledge, attitude, the perceived risks of infection and sources of information about HIV/ AIDS among pregnant women in an urban population of Delhi. J Commun Dis 2002;34:23-24.

30. Castle S. Doubting the existence of AIDS: A barrier to voluntary HIV testing and counseling in urban Mali. Health Policy Plan 2003; 18:146-155.

31. Sebunya $C$. The educated still think ignorance is bliss. AIDS Anal Afri 1995; 5:16.

32. Tukutuku K, Muyembe- Tamfum L, Odio, Kandi $\mathrm{K}$, Ntumba M. Oral manifestations of AIDS in a heterosexual population in a Zaire Hospital. J Oral Pathol 1989; 67:292-295.

33. Gileva O, Sazhina M, Gileva E, Efumov A, Scully C. Spectrum of oral manifestations of HIV/AIDS in the Perm region (Russia) and identification of self-induced ulceronecrotic lingual lesions. Med Oral 2004; 9:212-215.

34. Ceballos- Salobrena, Aguirre- Urizar JM, BuganSebastian JV. Oral manifestations associated with human immunodeficiency virus infection in a Spanish population. Oral Pathol Med 1996; 25:523526.

35. Ramirez- Amador V, Esquivel-Pedraza L, SierraMadero J, Ponce-de-Leon S, Ponce-de-Leon S. Oral manifestations of HIV infection by gender and transmission category in Mexico City. J Oral Pathol Med 1998; 27:135-140.

36. Robinson PG, Challacombe SJ, Sheiham A, Zakrzewska JM, Is erythematous candidiasis associated with advanced HIV disease? Oral Dis 1997; 3:S116-118.

37. Convissar RA. Laser palliation of oral manifestations of human immunodeficiency virus infection. JADA 2002; 133:591-598.

38. AIDS Institute. Oral health care for adults, adolescents, and children with HIV infection. Albany, N.Y: New York State Department of Health; 1998.

39. Scully C, McCarthy G. Management of oral health in persons with HIV infection. Oral Surg OralMed Oral Pathol 1992; 73:215-225.

40. Flaitz C, Nichols C, Hicks M. An overview of the oral manifestations of AIDS- related Kaposi's sarcoma. Compend Contin Educ Dent 1995; 15:136-148.

41. Chaisson RE, Gallant JE, Keruly JC, Moore RD. Impact of Opportunistic disease on survival in patients with HIV infection. AIDS 1998; 12:29-33.

42. McNulty A, Li Y, Radtke U, Kaldor J, Rohrsheim R, Cooper DA, Donovan B. Herpes zoster and the stage and prognosis of HIV-I infection. Genitourin Med 1997; 73:467-470.

43. Greenspan D, Greenspan JS. Management of the oral lesions HIV-infection. JADA 1991; 122:26-32.

44. Regezi JA, Sciubba J. Oral Pathology. Clinical Pathologic Correlations. $2^{\text {nd }}$ ed. WB Saunders CO. Philadelphia. 1993; 136-160.

45. Greenspan D, Greenspan JS, Conant M, Petersen V, Silverman S, DeSouza Y. Oral “hairy” leukoplakia in male homosexuals: evidence of association with both papilloma virus and a herpes group virus. Lancet 1984; ii:831-834.

African Journal of Reproductive Health Vol. 10 No.2 August 2006 
46. Muzyka BC, Kamwendo L, Mbweza E, Lopez NB, Glick M, Matheson PB, Kershbaumer R, Nyerienda T, Malamud D, Costantine NT, Thompson J, Nyasulu Y, Saville R, Berthold P. Prevalence of HIV1 and oral lesions in pregnant women in rural Malawi. Oral Surg Oral Med Oral Pathol Oral Radiol Endod 2001; 92:56-61.

47. Arendorf 'TM, Bredekamp B, Cloete CA,Sauer G. Oral manifestations of HIV infection in 600 South African patients. J Oral PatholMed 1998; 27:176-179.

48. Schiodt M, Bakilana PB, Hiza JFR, Shao JF, Bygbjerg IB, Mbaga I, Vestergaard BF, Nielsen CM, Lauritzen E, Lerche B, Kuijlen K. Oral candidiasis and HL correlate with HIV infection in Tanzania. Oral Surg Oral Med Oral Pathol 1990; 69:591-596.

49. Naidoo S, Chikte U. HIV/AIDS- the evolving pandemic and its impact on oral health in subSaharan Africa. S Afr Dent J 1999; 54:616-630.

50. Denning DW. The neurological features of acute HIV infection. Biomed Pharmacother 1988; 42:11-14.

51. Wiselka MJ, Nicholson KG, Ward SC, Flower AJ. Acute infection with human immunodeficiency virus associated with facial nerve palsy and neuralgia. J Infect 1987; 15:189-190.

52. Mastroianni A, Coronado O, Manfredi R, Chiodo F. Bell's palsy in HIV infection. Minerva Med 1994; 85:117-117. 